\title{
地理教育データベースの開発と試行
}

一1980年以降の地理教育研究動向の一分析—

山口幸男・相澤善雄・向後 武

平澤 否・松岡路唀・浅田 学

\section{I . 研究の目的と経過}

情報化社会の今日，ぞの学問分野に和いてもデ ーダベースの開発は重要な研究課題となってい る。地理学に関しては人文地理学会による「地理 学文献目録」とそのデータベース化や1), 雑誌 「地理」のデータベース化2) がなされ，社会科教 育に関しては将来のデータベース化をにらんで, 日本社会科教育学会が「社会科教育文献目録」を 継続的に刊行して跱り3)，教科教育全体に関する データベース化の研究も進行中である4)。また, 東京都立教育研究所もシソーラスの研究を行い 5)，その中に地理シソーラスがある。ただし，そ の内容は地理学的内容に関する面が強く, 必らず 乙も地理教育のシソーラスとは言いがたい。

このように，近接分野でのデータベース化は進 えでいるものの, 地理教育独自のデータベース化 は未開発の状況に山る。わが国の地理教育の発 展・充実をはかるためには, 地理教育独自のデー タベース化が不可欠との認識から, 日本地理教育 学会企画委員会では表記の委員でその開発を進め てきた。1992年 6 月から1993年10月までに 9 回以 上の会合を重ね，1992年10月には地理教育シソー ラス及び文献カード（検索カード）の開発に関す る中間報告を同学会例会にて発表し, 更に, その 結果をふまえた改善案を1993年 8 月の同学会研究 発表大会 (日本大学文理学部) にて発表した。ま た，全国的な学会誌を対象に，1980年以降の地理 教育の文献を收集してデータベースを試行的に作 成し，それに基づいて地理教育研究動向の一分析 を行った。その結果も，8月の大会にて，シソー ラスと合わせて発表した。

本稿は, 地理教育データベースの開発のための
地理教育シソーラスと文献カード（検索カード） の作成, 及びデータベース活用の一事例として行 った1980年以降のわが国に和ける地理教育研究動 向の一分析について述べるものである。

\section{II . 地理教育シソーラスについて}

\section{1. 地理教育シソーラス}

開発したシソーラスは（表 1), 大大項目ともい らべき “地理教育学” の下に, 次の 9 つの大項目 からなっている。《1. 地理教育理論》， $\ll 2$. 地 理教育史 $\gg, ~ \ll 3$. 比較地理教育》, $\ll 4$. 地理の 教育課程 $\gg, \ll 5$. 地理教科書, 副読本 $\gg, \ll 6$. 教材論 - 内容論, 授業実践 $\gg, \ll 7$. 学習指導法 $\gg$, 《8. 地理の学習心理, 意識, 認識, 発達》, 《9. 評価・授業分析》である。その下に，それぞ れ中項目を,さらにその下に必要に応じて小項目 を設けている。それぞれの論文は，このシソーラ スの中のどこかに位置づけられ，それを基にデー タベースを作るのである。

このシソーラスが完成するまでに，問題となり 検討したことは，次のようなことである。

\section{(1)地図関係の位置づけ}

当初から地図については，「教材としての地図」 と「学習方法としての地図学習」の二面性がある との意見が出された。第一次案では, 大項目 $\ll 7$. 学習指導法》の中に一括して含めることで提案し たが，例会で「教材としての地図」も重要である との指摘を受け，検討の結果，大項目 $\ll 6$. 教材 論・内容論, 授業実践》の中にる地図を入れるこ そにした。そのために，2つの大項目に，同じ内 容の中項目＜地図〉が存在することになった。

(2)環境教育，国際理解教育の位置づけ

環境教育と国際理解教育には, 理論的研究と実 
地理教育シソーラス

大 項 目

中 項 目

小項目

1 地理教育理論

1-1 地理教育の本質・性格

$1-2$ 地理教育の目標

知識(ミニマムエッセンシャルズ)・理解，地理的見方・考方方，地理的思考力

能力・技能

興味関心・意欲

$1-3$ 系統地理教育論

態度, 行動・実践力

$1-4$ 自然地理教育論

自然地理先習諭

$1-5$ 地誌教育論・地城区分論

$1-6$ 社会科地理教育論

$1-7$ 地理科独立論

$1-8$ 郷土地理教育諭・地域学習論

1-9 地理の基本概念・構造

1 -10 環境論

1-11 地域論, 地域主義

$1-12$ 景観論, 風景論

$1-13$ 国際理解教育

1-14 平和教育 $\cdot$ 人権教育

異文化理解, グローバルエデニケーション, 開発教育

$1-15$ 環境教育

1ー16 情報教育, メディア教育

1-17 学習指尊要領

1-18 教員坫成, 地理教師論

1-19 生涯教育 - 社会教育々地理教育

$1-20$ 地図教育論

1 -21 地理学々地理教育

$1-22$ 教育地理学

1 -23 関連分野

2 地理教育史

1 -24 その他

社会科, 歴史, 公民, 現代社会, 生活科, 理科, 国語科, 音楽科, 厹の他

$2-1$ 近世以前の地理教育

$2-2$ 明治の地理教育

$2-3$ 大正の地理教育

2-4 昭和戦前の地理教育

$2-5$ 戦後の地理教育

3 比較地理教育

$2-6$ その他

$3-1$ 世界

$3-2$ アシ்ア

$3-2-1$ 中国

$3-2-2$ 韓国

$3-2-3$ その他東アジフ

$3-2-4$ 東南アジア, 南アジア, 西アジア, 他

3 -3 アフリカ

$3-4 \quad \exists$ ロッパ

3-4-1 イギリス

$3-4-2$ フランス

$3-4-3$ ドイッ

$3-5$ 旧ソ速

$3-4-4$ その他

3-6 北アメリカ

ロシア，他

$3-6-1$ アメリカ合衆国

$3-6$-2 カナダ

$3-6-3$ その他

$3-7$ 中南アメリカ

$3-8$ オセアニア

3 -8一-1 オーストラリア

$3-8-2$ ニュージーランド

4 地理の教育䛞程

$3-8-3$ その他

4-1 地理カリキュラム諭一般

系統地理的カリキュラム 


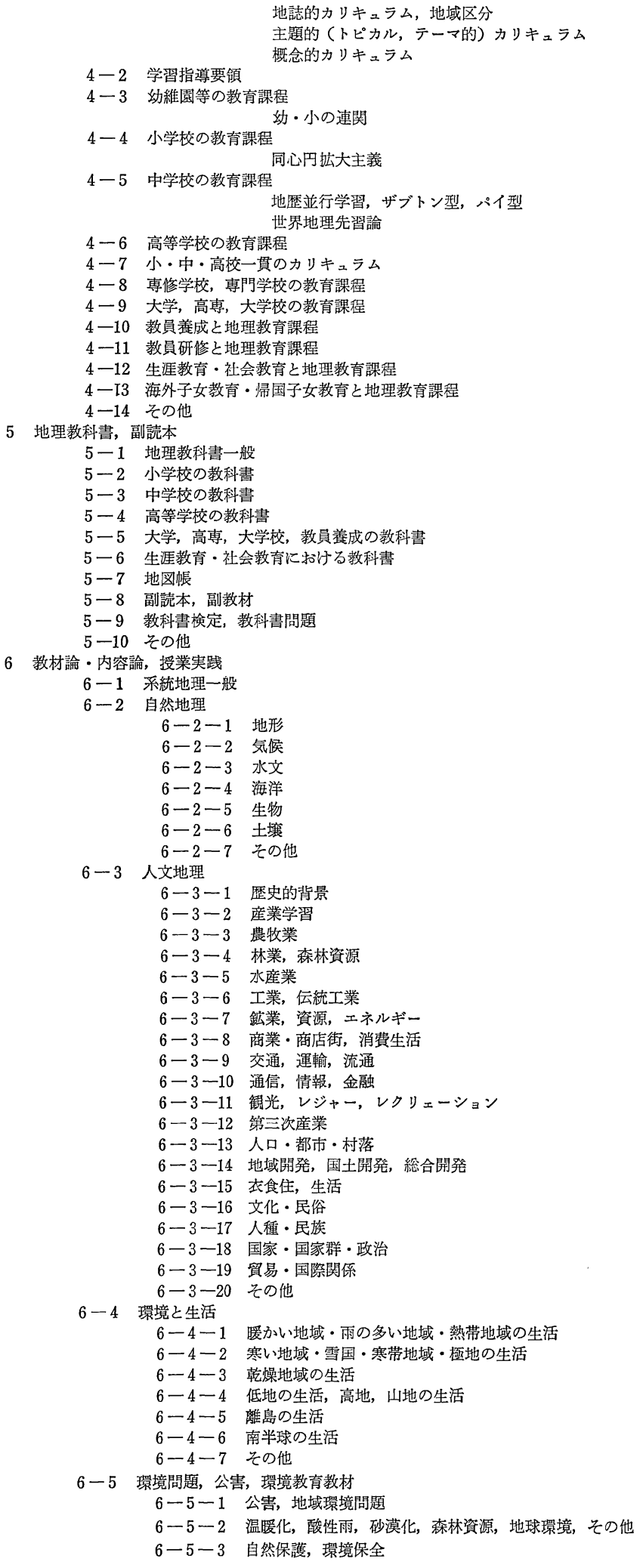




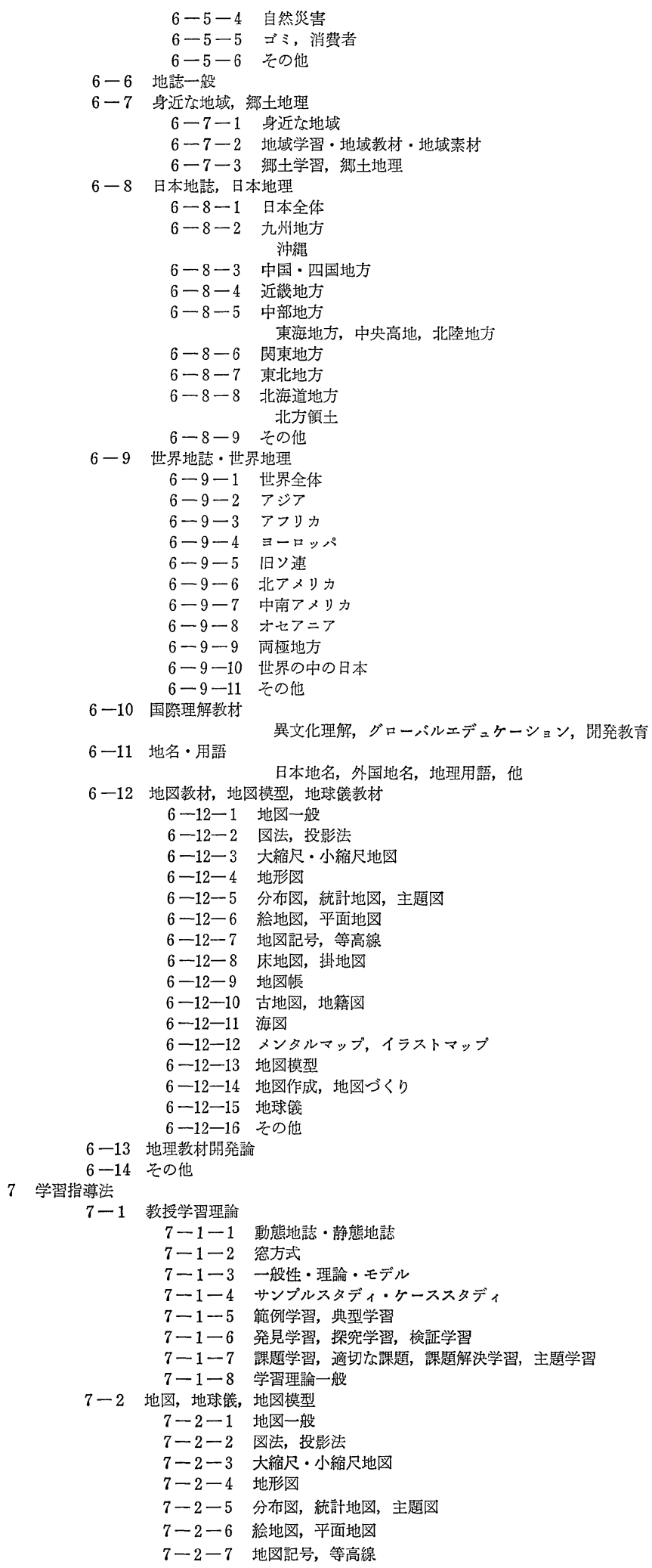




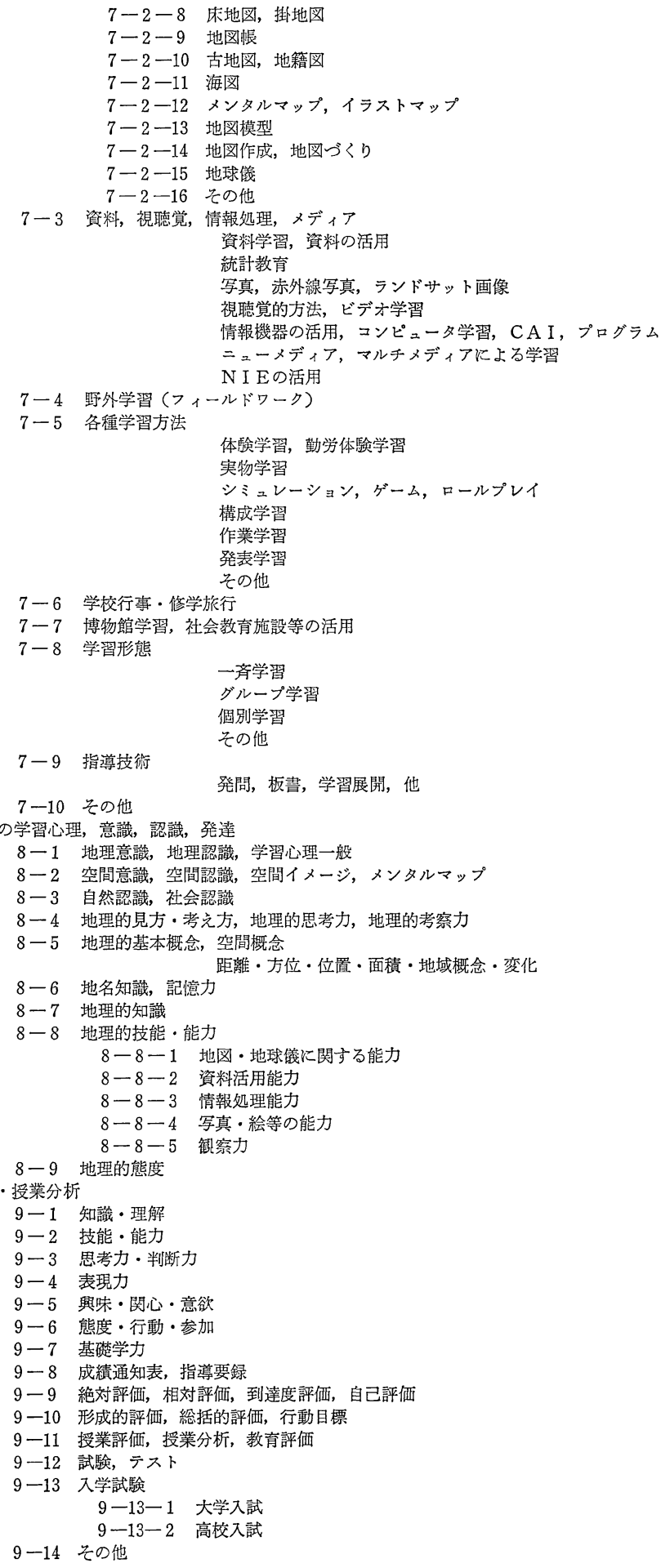


践的研究とがあるので, 前者をく1. 地理 教育理 論》に，後者を《6. 教材論・内容論，授業実践》 に位置づけた。

(3)戦後の地理教育史に関する研究の位置づけ

戦後の地理教育史に関する研究を教育史の項目 に含めるか否かといらことが問題になった。いろ いろな論議の結果，一度は教育史の中から除外す ることにしたが，初期社会科等の教育史的研究も 多く蓄積することから入れることになり，大項目 $\ll 2$. 地理教育史 $\gg$ のに $<2-5$. 戦後の地理 教 育〉といら中項目を設けた。

\section{(4)環境地理の位置づけ}

近年，環境地理という言葉が使われ（福岡199 2), ${ }^{6 ）}$ その言葉からして, $<6-2$. 自然地理 $><6$ -4. 環境と生活 $><6$ - 5 . 環境問題 $>$ な゙の中項 目の中への分類が考えられる。大会での発表で は，環境地理の項目を $<6-2$. 自然地理 $>$ 小項 目として位置づけたところ異論があった。そこ で，企画委員会で検討した結果，前述の著書も内 容的には環境問題と関わりが深く，環境地理を独
立した中項目とすることは時期尚早ということに なった。では，どこの中項目の中に入れるかとな ると判断が難しく, したがって現時点では環境地 理という項目は設けず，将来的に，研究が進展し た段階で再考することにした。

\section{2. 文献カード（検索カード）}

文献の收集及びデータの検索に物いて文献カー ド（検索カード）が必要となる。本委員会で開発 した文献カード（検索カード）は表 2 の通りであ る。このような文献カードをもとにコンピュータ の画面の中で検索できるのである。

カード内の「分類番号」は，地理教育シソーラ スに基づく分類番号で，大・中・小項目名を入れ る。その次の (一 一) には，文献がシソーラス 内の他の分類にも関連する場合, 第二分類とし て，その分類番号を入れる。そうすれば，下の 「関連項目名」に，第二分類としての項目名が自 動的に示される。

「種別」とは，収集した文献を文献の種類別に

表 2 地理教育文献カード

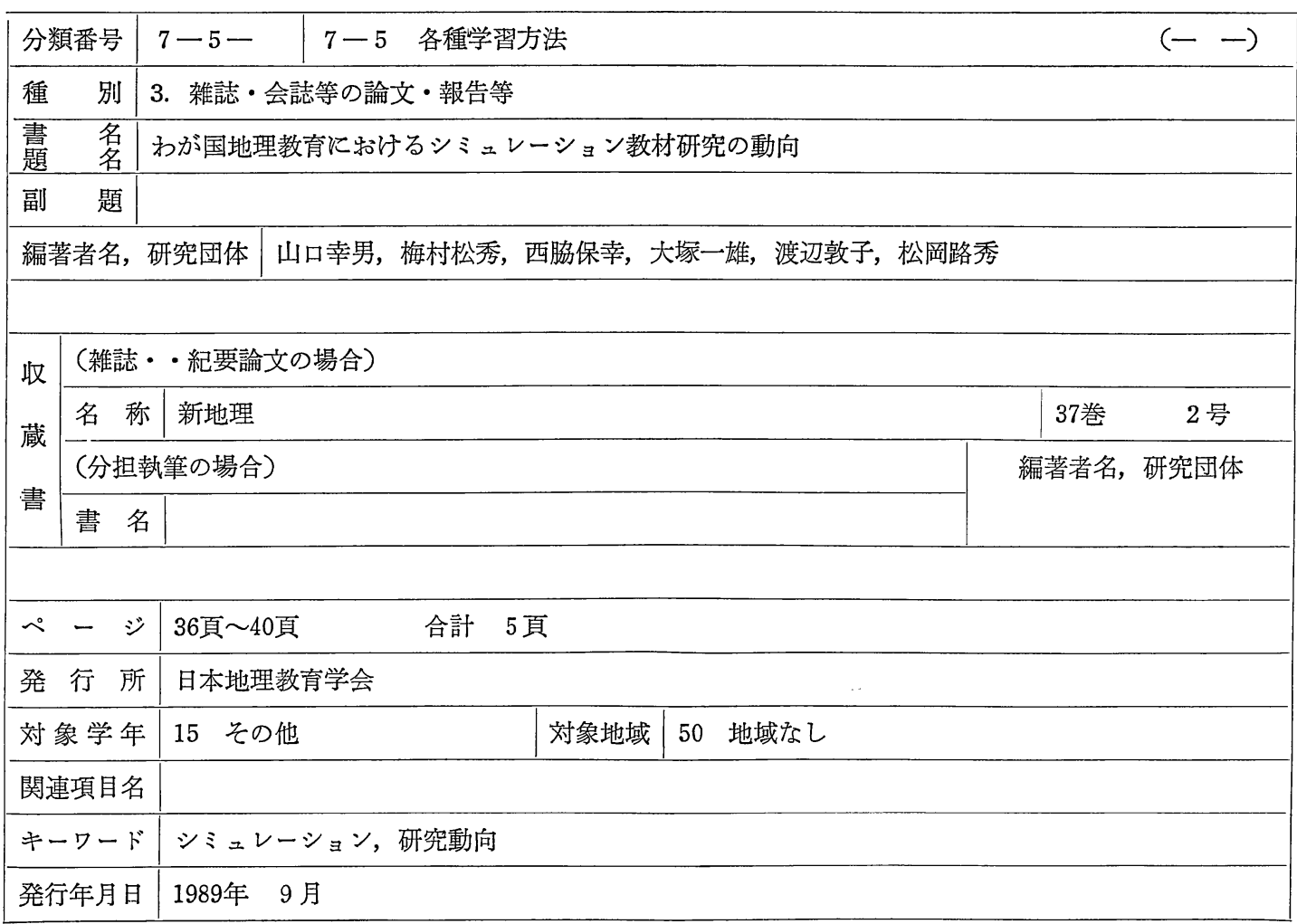


分類して，検索でさるようにするものである。そ の種別は，次のと括りである。

\section{1. 著書 (単著)}

2. 著書 (共著, 分担執筆)

3. 雑誌・会誌等の論文・報告等（論文, 研 究ノート, 報告, 短報, 記録, 資料等を 含む)

4. 研究報告書 (科研費乞の他)

5. 研究報告書（科研費气の他）の分担執筆

6. 抄訳

7. 書評

8. その他

「対象学年」とは，収集した文献を，その文献 が研究対象としている学校, 学年別に分類して, 検索できるようにするものである。その種別と は，次のと括りである。

1. 幼児（幼稚園, 保育園）

2. 小学生

3. 小学生低学年

4. 小学生中学年

5. 小学生高学年

6. 小・中学生

7. 中学生

8. 小・中・高校生

9. 中・高校生

10. 高校生

11. 専修学校・専門学校生

12. 大学生, 高専生, 大学校生

13. 教員

14. 社会人

15. その他

「対象地域」とは，収集した文献を，その文献 が対象としている地域別に分類して，検索できる ようにするものである。その種別とは，次のとお りである。
1. 日本全体
21. 世界全体
2. 九州地方
22. アジア
3. 中国・四国地方
23. アフリカ
4. 近畿地方
24. ヨーロッパ
5. 中部地方
25. 北アメリカ
6. 関東地方
26. 中南アメリカ
7. 東北地方
27. オセアニア
8. 北海道地方
28. との他（世界）
9. その他 (日本)
50. 地域なし

\section{3. 文献の収集範囲と収集方法 (1)収集文献の範囲}

地理教育に関する文献と一言でいっても，專門 書から児童向けの図書, 論文から授業資料に至る まで多種多様なものが含まれている。そこで，今 回の地理教育データベースの開発に際しては, 収 集する文献に次のような制限を設けた。

1. 地理教育に関する文献 (地理学研究は除く)

2. 国内で発表された文献

3. 1985年 1 月〜1992年12月に公刊されたも の。

4. 4000字以上（図表部分は字数に換 算す る) の長さのものとする。

5. 児童・生徒向けの図書及び一般図書は除 く。

(2)収集方法

文献の収集は, 学会員の自己申告を原則とし, 新地理40巻 4 号（1993年 3 月）に，地理教育文献 目録及びデータベース作成のための自己申告を， 会員に和願いした。企画委員会でも基本的な論文 については収集した。

\section{III. データベースを活用した地理教育研究 動向の一分析}

\section{1. 分析の方法}

データベース作成の一試行として, 全国的学会 誌 6 誌を対象に文献を収集した。さらに，活用の 一事例として, 地理教育研究動向の分析を行っ た。対象とした 6 誌とは，「新地理」(日本地理教 育学会),「地理学評論」(日本地理学会),「人文 地理」(人文地理学会), 「地図」(国際地図学会), 「社会科教育研究」(日本社会科教育学会),「社会 科研究」(全国社会科教育学会)である。

対象誌が 6 誌に限られ, 試行でもあるので, 期 間を自己申告の文献収集期間より長い1980１992 年とした。データベースの作成には「桐Ver. 4 」

(侏)管理工学研究所) を用い, 動向の分析には 「Lotus1-2-3R2.3J」（ロータス株式会社）も使 
用した。

\section{1980年以降の地理教育研究動向}

合計で 204 本の論文がリストアップされた。以 下に，幾つかの観点から分析した結果を述べる。

\section{(1)掲載雑誌別論文数（図 1)}

「新地理」所収の文献が 115 本 (56.4\%) 飞達 乙最も多い。「社会科教育研究」「社会科研究」 が，とれぞれ27本 (13.2\%),21本 (10.3\%) と比 較的多いのは当然のこととして，「地図」に 29 本 (14.2\%) の論文が発表されているのは, 地理教 育に括いて地図教育が重要であることを示してい る。

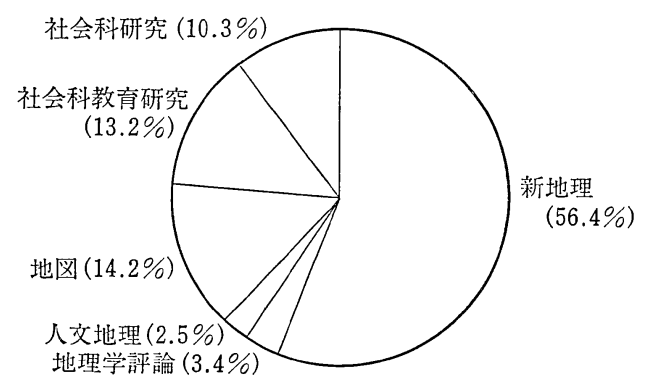

図 1 地理教育研究の論文数 揭載雑誌別

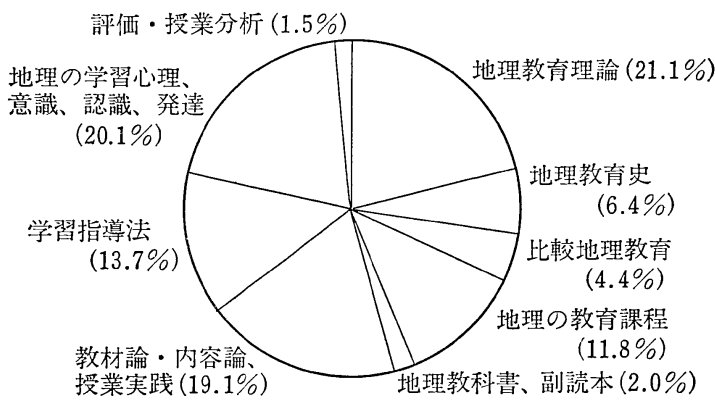

図 2 地理教育研究の論文数 項目別

一方, 「地理学評論」「人文地理」は 7 本, 5 本 とそれぞれ少ない。日本地理学会, 人文地理学会 といら学会の性格上やむを得ない面もあるが, 地 理学と地理教育の結び付きの弱さが露呈している ようである。

\section{(2)項目別論文数（図 2)}

大項目に基づいて論文数を数えると，最も多い 項目は，「地理教育理論」で43本 (21.1\%) であ る。次いで「地理の学習心理, 意識, 認識, 発達」 の41本 $(20.1 \%)$ ，「教材論・内容論，授業実践」 の39本 $(19.1 \%)$ が続く。以下，「学習指導法」
28本 (13.7\%), 「地理の教育課程」24本（11.8 $\%)$, 「地理教育史」13本 (6.4\%) の順である。

「教材論…」「学習指導法」の 2 つを授業に直接 関わるものとして合わせて考えると，32.8\%とな り，ほぼ 3 分の 1 を占める。地理教育研究が実践 に土台を特いていると考光て良いだろう。乙か し，授業実践のもととなるべき「地理教科書，副 読本」が 4 本 $(2.0 \%)$ と，諭文数が少ない。こ のことは，今後解決すべき課題として指摘するこ とができよう。

\section{(3)地理教育の論文数の年次別变化}

図 3 を見てわかるように，地理教育関連の論文 数は，年を追う毎に増加している。特に1990（平 成 2 ) 年には前年度の倍にあたる36本の諭文が発 表された。これは前年度の1989 (平成元) 年に学 習指導要領が改訂されたことと関係があるかも知 れない。以下論文数が比較的多い5つの項目につ いて年次別の変化を考察する。

(1)地理教育理論 (図 4)

1982 (昭和57) 年, 86（昭和61）年，88（昭和 63）年に論文数が増えるが，全体的にはコンスタ ントに論文が発表されている。86，88年に発表さ れた論文に特徽的な共通性はない。

(2)地理の教育課程（図 5 )

全般的に論文数は少ないが，1990（平成 2) 年 の論文数の増加が顕著である。その年の11本の論 文の内，10本までが「地図」 28 巻 3 号揭載のもの であり，その号が地図教育に関する特集号であっ た結果であるら。

(3)教材論・内容論，授業実践（図 6)

83年以降，年を追ら毎に論文数は増加してい る。90年にやはり論文数の顕著な増加がみられる が，11本中 4 本が「地図」 28 巻 3 号収録の論文で ある。

(4)学習指導法 (図 7)

89年以降, 論文数が急激に増加している。教育 課程や教材論・内容論，授業実践と同じく，1990 (平成 2 ) 年に顕著な増加が見られる。その 9 本 中 6 本が「地図」28巻に揭載された論文で，これ らは $2 \sim 4$ 号に分散して揭載されている。

91，92年にも比較的多数の論文が発表されてい るが，その中には「地図」掲載の論文は 2 本しか 


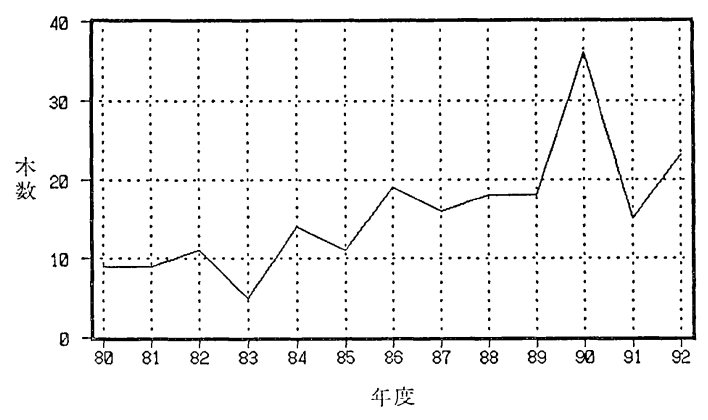

図 3 地理教育の論文数の年次別变化 全体

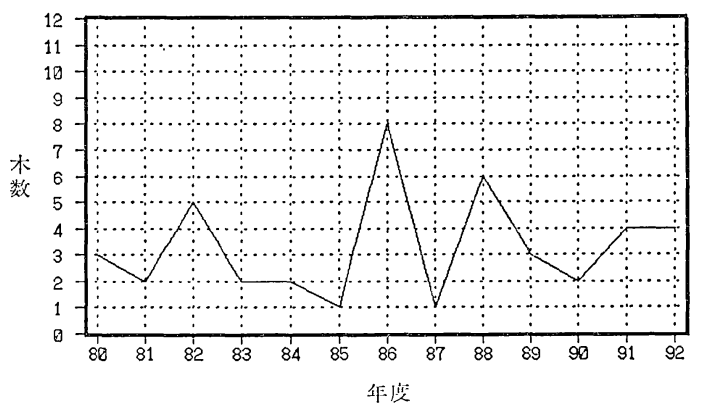

図4 地理教育の論文数の年次別变化 地理教育理論

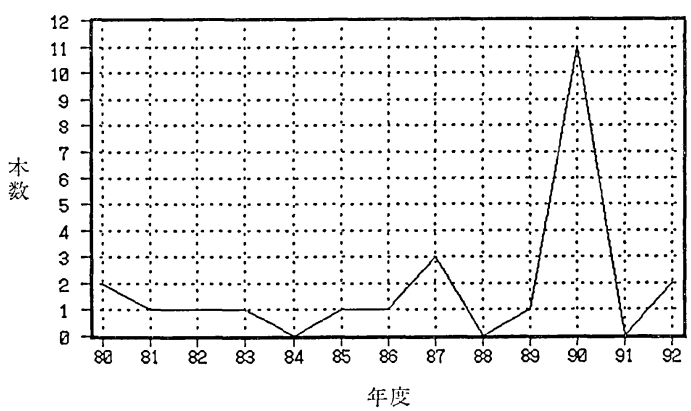

図 5 地理教育の論文数の年次別変化 地理の教育課程

含まれていない。

(5)地理の学習心理, 意識, 認識, 発達（図 8)

$1984 （$ 昭和59）年以降，年によって多萓はある が，コンスタントに論文が発表されている。その ほとんぞが「新地理」に揭載されたものである。 学習のための基礎的な研究である心理・認識面の 研究が日本地理教育学会で盛えに行われているこ とは，学会の設立主旨にてらしても，健全な活動 といえるだろう。

(4)対象地域 (表 3)

研究の対象地域が複数にまたがる場合は，最も 重点が祘かれていると判断した地域のみを対象地 域として扱った。また，対象地域を特定できない

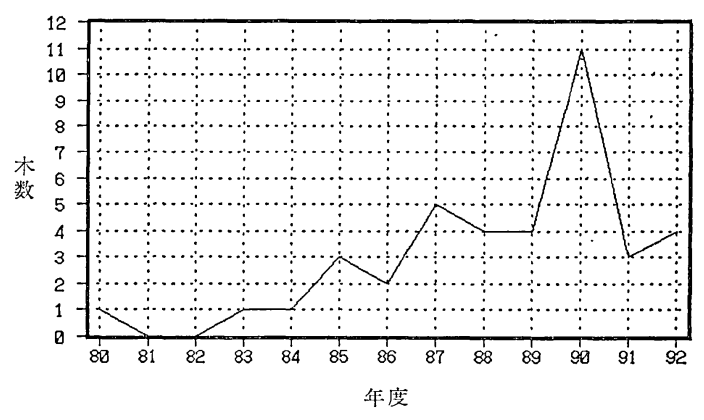

図 6 地理教育の論文数の年次別変化 教材論・内容論, 授業実践

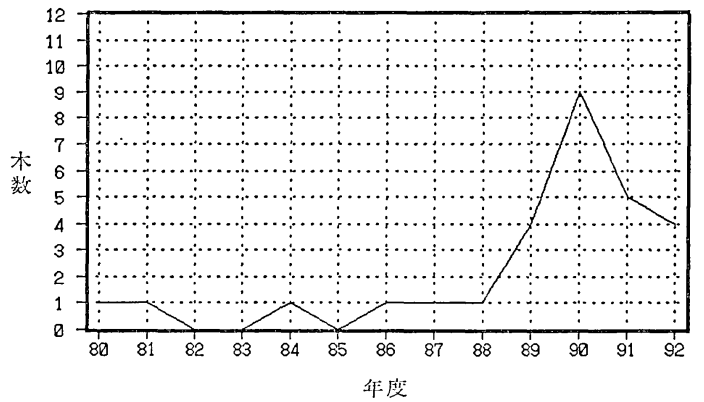

図 7 地理教育の論文数の年次別変化 学習指導法

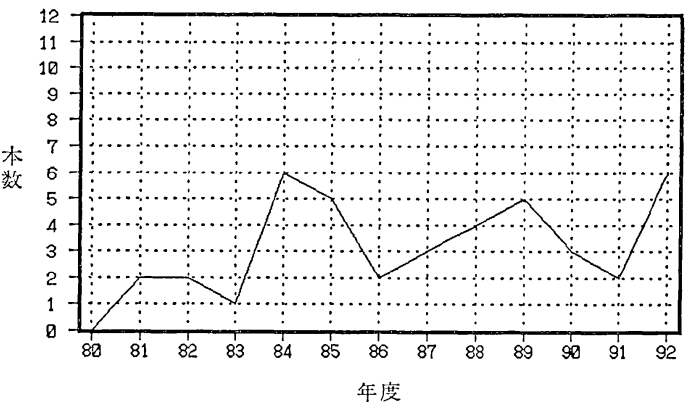

図 8 地理教育の論文数の年次別变化 地理の学習心理, 意識, 認識, 発達

論文もあるので，それらを除いて，合計で 104 本 の論文を分類し，表 3 の結果を得た。

3 分の 2 に市たる70本が日本を研究の対象と し，残りの34本が世界を研究対象としていた。

日本を研究対象としている論文の中では，日本 全体を対象地域としているものと，関東地方を対 象地域としているものがとれぞれ21本 (30\%) ず つある。次いで中部地方を対象地域としたものが 11本 $(15.7 \%)$ で多かった。

世界を研究対象としている論文の中では，世界 全体を対象地域としているものが12本 (35.3\%), アジアを対象地域としているものが 11 本（32.4 
表 3 対象地域別の論文数

\begin{tabular}{|c|c|}
\hline 対象地域 & 論 \\
\hline 日本全体 & 21 \\
\hline 九州地方 & 2 \\
\hline 中国・四国地方 & 6 \\
\hline 近畿地方 & 4 \\
\hline 中部地方 & 11 \\
\hline 関東地方 & 21 \\
\hline 東北地方 & 3 \\
\hline 北海道地方 & 2 \\
\hline 日本合計 & 70 \\
\hline 世界全体 & 12 \\
\hline アジア & 11 \\
\hline アフリカ & 2 \\
\hline ヨーロッパ & 5 \\
\hline 北アメリカ & 4 \\
\hline 中南アメリカ & 0 \\
\hline オセアニア & 0 \\
\hline その他（世界） & 0 \\
\hline 世界合計 & 34 \\
\hline 合計 & 104 \\
\hline
\end{tabular}

\%)となっている。

日本にせよ世界にせよ，研究対象とする地域に 大きな偏りがある。今後の研究の進め方に対して 一考を要するところであろら。

(5)対象学年 (表 4, 5)

研究対象とする学年を特定できない論文もある ので，それらを除き，合計で 164 本を対象とし た。

表 4 は文献カードの分類にそのまま従って作成 した表である。表 5 は重複を許したらえで，学校 区分別論文数を数えた表である。

小学生を対象学年としたものが最も多く95本, 次いで中学生対象の76本, 高校生対象の63本と続 くが，それ以外の論文は極端に少ない。
表 4 対象学年別の論文数

\begin{tabular}{|l|r|}
\hline 対象学年 & 論 \\
\hline 幼児 & 文 \\
\hline 小学生 & 3 \\
\hline 小学校・低学年 & 28 \\
\hline 小学校・中学年 & 0 \\
\hline 小学校・高学年 & 9 \\
\hline 小・中学生 & 8 \\
\hline 中学生 & 24 \\
\hline 小・中・高校生 & 15 \\
\hline 中・高校生 & 26 \\
\hline 高校生 & 11 \\
\hline 専修・専門学校生 & 26 \\
\hline 大学・高専・大学校生 & 3 \\
\hline 教員 & 9 \\
\hline 社会人 & 2 \\
\hline 合計 & 0 \\
\hline
\end{tabular}

表 5 学校区分別の論文数

\begin{tabular}{|c|c|}
\hline 対象学校 & 論 文 \\
\hline 幼児 & 3 \\
\hline 小学校 & 95 \\
\hline 中学校 & 76 \\
\hline 高校 & 63 \\
\hline 高校以上 & 12 \\
\hline 教員 & 2 \\
\hline 社会人 & 0 \\
\hline
\end{tabular}

地理教育が小学校から高校までの学校での教科 教育に限られることは, ある意味ではしかたない ことである。しかし, 生涯教育の重要性が叫ばれ 始めた現在, 地理の裾野を広げていく意味でも, 学校以外での地理教育にも目を向けるべきではな いだろらか。

\section{3. 特定分野に属する論文の検索・抽出}

ある特定の言葉（キーワード）に基づいて，特 定の分野に属する論文を検索・抽出することも可 
表 6 特定分野に属する論文の検絮・抽出「地図」

\begin{tabular}{|c|c|c|c|c|c|c|c|c|}
\hline & & 中小 & 題 & 副 題 & 者 & 雑 誌名 & 巻号 年 & \\
\hline 1 & & 20 & =ューメディフ時代の地図教育 & 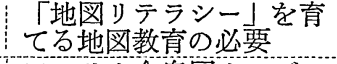 & 太田 & 地図 & $261: 1988$ & \\
\hline 2 & & 20 & 望玉しい地図教育について & $\begin{array}{l}\text { アメリカ合衆国カンザス } \\
\text { 大学を例とて }\end{array}$ & 高橋 重雄 & 新地理 & 3611988 & \\
\hline 3 & & 20 & $\begin{array}{l}\text { 䐓治前半期の地図教育の実践に関す } \\
\text { 每的研究 }\end{array}$ & & 田中 耕三 & 新地理 & 362 1988 & \\
\hline 4 & 1 & 20 & 地図教育の根底にあるものは何か & & 米地 文夫 & 地図 & 2831990 & \\
\hline 5 & & 20 & $\begin{array}{l}\text { 明治後半期の地図教育の実践に関す } \\
\text { る串的研究 }\end{array}$ & & 田中 耘三 & 新地理 & \begin{tabular}{ll|l|l|l|l|l|l|l|l}
39 & 1991
\end{tabular} & \\
\hline 6 & & 20 & $\begin{array}{l}\text { 大正 }- \text { 昭和前期の地図教育に関する } \\
\text { 的研究 }\end{array}$ & & 田中 耕三 & 新地理 & 4021992 & 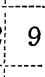 \\
\hline 7 & 4 & 80 & 海外の地罒学教育 & & 金沢 & 地図 & 2831990 & \\
\hline 3 & 4 & $8: 0$ & $\begin{array}{l}\text { 国土建設学院に和ける地図作成技術 } \\
\text { 者の荃成課程 }\end{array}$ & & 片江 & 地図 & 2831990 & \\
\hline 9 & 4 & 90 & 大学に和ける地図教育 & & 五條 英司 & 地図 & 2831990 & 5 \\
\hline & 4 & 90 & 大学を中心とする地図教育 & & 大久保武彦 & 地図 & 2831990 & 9 \\
\hline 11 & & 120 & 公開講座に和ける地図学習 & 追手門学院大学の場合 & 池田 晶一 & 地図 & 2831990 & 9 \\
\hline 12 & & 140 & 国際教育の場に招ける地図教育 & 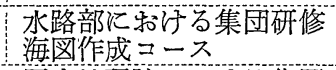 & 小山田安宏 & 地図 & 2831990 & 9 \\
\hline 13 & & 140 & 国際協力の場に和ける地図教育 & $\begin{array}{l}\text { 国土地理院に和汀る集団 } \\
\text { 研修測量技術コース }\end{array}$ & 小須 加洋 & 地図 & 2831990 & 9 \\
\hline 14 & & 140 & 地図調整会社に扮ける技術者教育 & & 奥 & 地図 & 2831990 & 9 \\
\hline 15 & 6 & $\begin{array}{lll}7 & 3 \\
\end{array}$ & 諏訪地図による郷土学習 & & 伊藤 光彦 & 地図 & 2831990 & 9 \\
\hline 16 & & & 小・中・高等学校に和ける地図学習 & $\begin{array}{l}\text { 地図教育に使用する語句 } \\
\text { の選点覧 }\end{array}$ & 伊藤 & 地図 & $\begin{array}{llll}30 & 1 & 1992 \\
\end{array}$ & 3 \\
\hline 17 & & 121 & 『好きこそ地図の..............』 & & 山口 裕一 & 地図 & 2831990 & 9 \\
\hline 18 & & 12 & 地図教育と情報 & & 岩佐 武彦 & 地図 & 2831990 & 9 \\
\hline 19 & & 121 & 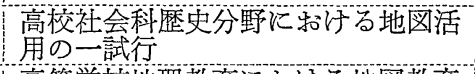 & & 新田 牧雄 & 地図 & $\begin{array}{llll}29 & 1 & 1991 \\
\end{array}$ & 3 \\
\hline 20 & & 125 & 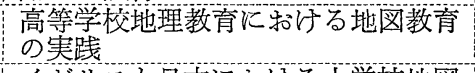 & & 大塚 一雄 & 地図 & 2831990 & 9 \\
\hline 21 & & 129 & 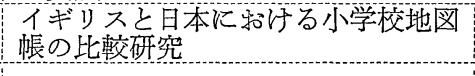 & & 吉田 和義 & 新地理 & 3831990 & 12 \\
\hline & & 1214 & 児童の歩測による地図づくり & 小学校第 4 学年に打活る & 寺本 & 新地理 & $\begin{array}{llll}31 & 3 & 1983 \\
\end{array}$ & 12 \\
\hline & 6 & 1215 & 郷土地図と地四教育 & 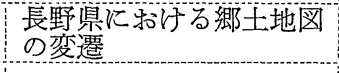 & 伊藤 光彦 & 地図 & \begin{tabular}{l|l|l}
27 & 2 & 1989
\end{tabular} & 6 \\
\hline & 7 & 21 & 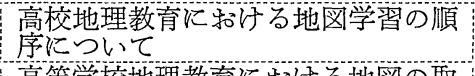 & & 伊藤 & 地図 & 2631988 & 9 \\
\hline & 7 & \begin{tabular}{l:l}
2 & 1 \\
\hdashline
\end{tabular} & 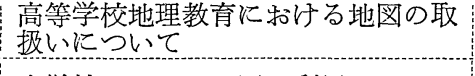 & & 菊沢 健生 & 地図 & 2821990 & 6 \\
\hline & 7 & 21 & 中学校に和ける地図の利用 & & 前田 吉穂 & 地図 & 2831990 & 9 \\
\hline & 7 & $2: 1$ & 高筧学校社会科地理教育に和称る地 & & 伊藤 & 地図 & $\begin{array}{lll}28 & 3 & 1990\end{array}$ & 9 \\
\hline & 7 & \begin{tabular}{c:c}
2 & 1 \\
\hdashline
\end{tabular} & 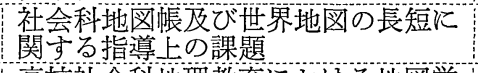 & & 渋沢 文隆 & 地図 & 2921991 & 6 \\
\hline & 7 & $2: 3$ & 高校社会科地理教育に和汀る地図学 & $\begin{array}{l}\text { 地図学畾で利捅する小縮 } \\
\text { 図法らいて }\end{array}$ & 伊藤 & 地図 & $284: 1990$ & 12 \\
\hline & 7 & 24 & 地理教育に括汓る地四学習の課題 & & 溙沢 文隆 & 地図 & $27 \quad 1 \quad 1989$ & 3 \\
\hline & 7 & 24 & 高校社会科地理教育に和汀る地図学 & 地形図の利用 & 伊藤 & 地図 & 2821990 & 6 \\
\hline & 7 & 215 & 高校社会科地理教育における地図学 & 古地図の利用 & 伊藤 & 地図 & 2921991 & 6 \\
\hline & 7 & 215 & 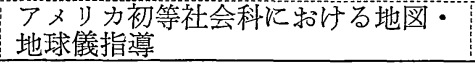 & & 田部 俊充 & 新地理 & 3941992 & 3 \\
\hline
\end{tabular}


表 7 特定分野に属する論文の検索・抽出「国際」



表 9 特定分野に属する論文の検索・抽出「環境」

\begin{tabular}{|c|c|c|c|c|c|c|c|c|}
\hline & 大中小 & 題 名 & 題 & 著 & 者 & 雑 誌名 & 巻号 年 & 月 \\
\hline 1 & 1150 & $\begin{array}{l}\text { 小学校・中学校に持ける「環 境教 } \\
\text { 充」琴状と題点 }\end{array}$ & & 佐島 & 群巳 & 新地理 & 2811980 & 6 \\
\hline 2 & $1: 0$ & 中国の「自然常識」と環境教育 & & 作島 & 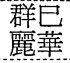 & 新地理 & 2911981 & 6 \\
\hline 3 & 1150 & イギリスに和污る環璄学習と環境教 & その歴史的変遷と現状 & 山下 & 宏文 & 社会科 & 471982 & 3 \\
\hline 4 & 1150 & 世界環境教育会議の報告 & & 佐島 & 群巳 & $\begin{array}{l}\text { 社会科 } \\
\text { 教育研究 }\end{array}$ & 551986 & 3 \\
\hline
\end{tabular}




\begin{tabular}{|c|c|c|c|c|c|c|c|c|c|}
\hline 5 & 1 & 150 & $\begin{array}{l}\text { ヒートアイランドを利用した環境教 } \\
\text { 育の展 }\end{array}$ & & 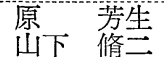 & 新地理 & 341 & 1986 & 6 \\
\hline 6 & & 150 & $\begin{array}{l}\text { 社会科に和污環境教育の重要性に } \\
\text { つ作 }\end{array}$ & カモシカの被害を事例と & 関根 & $\begin{array}{l}\text { 社会科 } \\
\text { 教育研究 }\end{array}$ & & 61992 & 1 \\
\hline 7 & & 150 & 知的市民性育成としての環境教育 & $\begin{array}{l}\text { イキリスの環境教育の発 } \\
\text { 展をもとに }\end{array}$ & $\begin{array}{l}\text { 任島 羣已 } \\
\text { 安 }\end{array}$ & 究会科研 & & 011992 & 3 \\
\hline 8 & 6 & $5: 1$ & $\begin{array}{l}\text { 小学生の多摩川観に関する環境論的 } \\
\text { 考察 }\end{array}$ & & 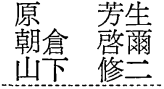 & 新地理 & 371 & 1989 & 6 \\
\hline 9 & 7 & 30 & 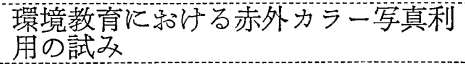 & & 伊藤 等 & 新地理 & 282 & 1980 & 9 \\
\hline 10 & 8 & 20 & $\begin{array}{l}\text { 子ぞもの心像環境における身近な } \\
\text { 地域」の構造 }\end{array}$ & & 岩本 広美 & 地理学評 & 54 & 1981 & 3 \\
\hline 11 & 8 & 20 & $\begin{array}{l}\text { 子と碟的研究 } \\
\text { 知賞環璄の発達関する基 }\end{array}$ & & 寺本 & 訑理学評 & 572 & 1984 & 2 \\
\hline 12 & 8 & 20 & 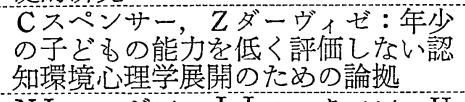 & & 安藤 正紀 & 新地理 & 331 & 1985 & 6 \\
\hline 13 & 8 & 20 & 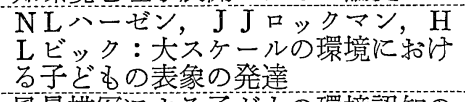 & & 松井美佐子 & 新地理 & 331 & 1985 & 6 \\
\hline 14 & 8 & 20 & $\begin{array}{l}\text { 風景描写による子どの環璄認知の } \\
\text { 登焦過程に関する研究 }\end{array}$ & & 岩川 朝培 & 新地理 & 361 & 1987 & 6 \\
\hline 15 & 8 & 30 & $\begin{array}{l}\text { 臬然環境，特に水文環境に対する大 } \\
\text { 意識について }\end{array}$ & & $\begin{array}{ll}\text { 菒原 } & \text { 正治 } \\
\text { 鈴木 } & \text { 裕熄雄 } \\
\text { 島野 }\end{array}$ & 新地理 & 304 & 1983 & 3 \\
\hline
\end{tabular}

能である。自分の研究分野で今までどのような論 文が発表されているかを確認する場合等に有効な 利用法である。今回は,「地図」「国際」「環境」 について検索・抽出してみた。

「キーワード」といら項目が文献カードにある が，今回はその「キーワード」ではなく，論文の 題名を利用した検索・抽出を試みた。

(1)地図 (表 6)

論文の題名に「地図」という単語が含まれてい る論文を検索・抽出すると，33本の論文が検索・ 抽出された。

大項目別に見ると，「地理教育理論」に含まれ ているもの 6 本, 「地理の教育課程」が 8 本, 「教 材論・内容論, 授業実践」 9 本,「学習指導法」 10本といら内訳である。実際の授業に直接関わる 研究が多いことを示した内訳であるう。

また，雑誌別では，当然のことながら「地図」 に多く26本，「新地理」に7本となっている。

(2)「国際」(表 7 )

題名に「国際」「世界」「異文化」「グローバル」 といら単語が含まれている論文を検索・抽出する そ，26本の論文が検索・抽出された。

大項目別の内訳は, 「地理教育理論」11本, 「地 理の教育課程」 3 本, 「教材論 - 内容論, 授業実 践」5本, 「学習指導法」 1 本, 「地理の学習心
理, 意識, 認識, 発達」6本で山る。研究の動向 が，実践よりも理論に偏っているといえるだろ ら。

雑誌別内訳では，「新地理」11本，「社会科教育 研究」10本, 「地図」 3 本, 「地理学評論」「人文 地理」各 1 本となっている。

(3)「環境」(表 8)

題名に「環境」という単語が含まれている論文 を検索・抽出すると，15本が検索・抽出された。 大項目別に見ると,「地理教育理論」7 本, 「教材 論 - 内容論, 授業実践」「学習指導法」各 1 本,

「地理の学習心理, 意識, 認識, 発達」 6 本とい ら内訳である。

「地理教育理論」に含まれている論文は環境教 育に関連するものが多く,「地理の学習心理, 意 識, 認識, 発達」に含まれている論文は環境認知 に関するものが多い。このように 2 つの傾向を持 つ論文群が同時に検索・抽出されたのは, 題名で の検索を行ったためである。「キーワード」の項 目での検索や，条件の精選を行点ば，このような 混交は避けられるであるう。

雑誌別の内訳では,「新地理」9本,「社会科教 育研究」 3 本, 「地理学評論」 2 本, 「社会科研 究」 1 本となっている。 
以上, 試行的に幾つかの観点からの分析を試み た。全体的に見て, 論文の発表は着実に伸び, 研 究が蓄積されている。しかし, 研究対象とされる 領域, 地域, 学年に偏りが見られる。今後, 地理 教育研究をこれらの偏りを埋めるようにして進 め, 全面的な発展を目指すことが必要だろら。

な持, 上記の分析はデータベース活用の一事例 として行ったものであること, また, 対象文献が 限られているので, わが国の地理教育研究動向の 全体ではないことを改めて指摘して特きたい。

\section{N.おわりに}

本稿は, 日本地理教育学会企画委員会が 3 年計 画 (平成 $4 \sim 6$ 年度) で行っている地理教育デー タベースの開発に関する共同研究の成果を中間的 に報告したものである。シソーラスの開発にし ろ,データベースの開発・試行にしろ，まだ十分 とはいえないがわが国初の試みとして貴重な意 義を持つと考学る。読者諸氏の忌憚のないご批 判, ご教示を得て, 今後, 一層十全なものに改善 していきたい。

現在, 企画委員会では会員諸氏の自己申告文献 カードをもとに，地理教育文献目録の作成とその データベース化の作業を進めて持り, 近いらら
に，その結果を公表する予定である。

\section{参考文献}

1）人文地理学会編『地理学文献目録第 9 集（1987～ 1991』『同フロッピー版』(古今書院), 1993 年 3 月。

2)『地理」総索引フロッピー版』（古今書院）, 1992 年。

3）日本社会科教育学会編『社会科教育文献目録 1980 ～1989第 3 集』，1990年10月。

4）降旗勝信（代表）『教科教育以和祆る教育実践情 報に関するデータベース化の開発研究』全 284 頁, 科研費総合研究 $\mathrm{A}$ 研究成果報告書, 1992年 3 月。

5）東京都立教育研究所教育シソーラス開発プロジェ クト『教育シソーラス開発試案一地理編一』, 1986 年 3 月。

6）福岡義隆『図説環境地理』(古今書院)，1992年 6 月。

(山口: 群馬大学教育学部)

（相澤 : 都立豊多摩高校）

(向後 : 都立水元高校)

(平澤 : 埼玉大学教育学部附属中学校)

(松岡：神奈川県大和市立大和中学校）

(浅田 : 新宿区教育委員会) 